\title{
Erratum to: Sealing of polymer micro-structures by over-moulding
}

\author{
Mathias Vingaard • Jesper deClaville Christiansen
}

Published online: 20 December 2013

(C) Springer-Verlag London 2013

Erratum to: Int J Adv Manuf Technol Volume 61, Issue 1-4, pp 161-170

DOI 10.1007/s00170-011-3690-y

The electronic information of the article is incorrect and caused a discrepancy to the PDF format. First author's name was not included in the electronic version. The complete list of authors is presented in this paper.

The online version of the original article can be found at http://dx.doi.org/ 10.1007/s00170-011-3690-y.

M. Vingaard · J. deClaville Christiansen $(\bowtie)$

Department of Mechanical and Manufacturing Engineering,

Aalborg University, Fibigerstræde 16,

9220 Aalborg Ø, Denmark

e-mail: jc@m-tech.aau.dk 